MedieKultur | Journal of media and communication research | ISSN 1901-9726

\title{
Keeping cool, staying virtuous \\ Social media and the composite habitus \\ of young Muslim women in Copenhagen
}

\section{Karen Waltorp}

MedieKultur 2015, 58, 49-67

Published by SMID | Society of Media researchers In Denmark | www.smid.dk The online version of this text can be found open access at www.mediekultur.dk

This article builds on long-term anthropological fieldwork among young Muslim women in a social housing area in Copenhagen. It explores how morality, modesty, and gender- and generational relations become reconfigured in the ways in which young women use the smartphone and social media to navigate their everyday lives. I focus on love and marriage, the imperatives of appearing cool among peers, and keeping the family's honour intact through the display of virtuous behaviour. Building on Bourdieu's writings on the split habitus, I introduce the term composite habitus, as it underscores the aspect of a habitus that is split between (sometimes contradictory) composite parts. The composite habitus of the young women is more than a hysteresis effect (where disposition and field are in mismatch and the habitus misfires), as the composite habitus also opens up to a range of possible strategies. I present examples of how intimate and secret uses of smartphones have played out and show how social media have allowed for multiple versions of the self through managing public and secret relationships locally and across long distances.

\section{Keywords}

Social media, Muslim women, composite habitus 


\section{A vignette on romance on Facebook}

Bita, 24, a woman of Iranian origin (all names are pseudonyms), initiated a relationship on Facebook ${ }^{1}$ with a young Iranian man living in Dubai, and they have now been in a relationship for two years. Her mother knows about it, as do her friends. She and her boyfriend have never met "irl" (in real life), but their relation has evolved from a Facebook romance into communication within a more intimate media sphere, and they now use FaceTime or Viber $^{2}$ through which they can see each other while talking. She only sends him pictures with her veil off. He would not find wearing the veil "cool", as she says; it would imply that she was boring and old-fashioned, wearing the veil in a European city where nobody forced her to. He asked her to not be on Facebook. He is on Facebook himself, but he does not allow her to be. Since other young men might write her on Facebook, and he feels uncomfortable with her being visible in that way. In response to her boyfriend's demands, Bita has closed down her "old" account and established a new fake account (alias profile) on Facebook without his knowing it and has managed to acquire over 300 "friends" in common with him. She is monitoring him close, all the while he (thinks he) is controlling her visibility. Officially, she complies; but, through the smartphone and social media, she has made her own rules in the relationship. She is keeping cool and staying virtuous.

The young Muslim women with whom I worked inhabit a complex position in moral terms: How to imagine, and lead, a good and desirable life and be recognized as both a virtuous woman and a "cool" person, when you have to negotiate the often conflicting expectations from your family, the friends you grew up with in Denmark, and broader Danish society? In other words, what constitutes and how does one obtain "the good life"?

The Qur'an and the life of the Prophet Muhammad as set forth in the hadith and sunnah provide a set of fundamental guidelines for navigating everyday life. Negotiations with oneself and others regarding how to understand and implement these guidelines in a Danish context prompt debate about autonomy, sexuality, modesty and possible futures. These negotiations, I argue, take place in dynamic ways among these young women through the use of social media.

As in many other places in today's technologically-mediated world, smartphones are ubiquitous among young Muslim women in the social housing area in central Copenhagen in which I carried out ethnographic fieldwork (2014-2015) as part of my doctoral dissertation research. My prior research in the area (2010-2011) made it clear that smartphones figure as a central networking device with respect to people inside and outside of the social housing area and in broader transnational networks. In addition to their uses for accessing information and for communication, smartphones have been applied in a multitude of ways: As a tool for protection, gossiping, alliance-making, flirting, bullying, or trafficking drugs. They have been used for reading the Qur'an, geo-tagging, paying bills and communicating with municipal offices and social services; and they have been used for entertainment and "flashing" one's economic and technological capital. 
This article specifically explores the uses of social media by young Muslim women that make it possible for them to navigate (conflicting) expectations from relatives and friends and pursue otherwise incompatible strategies. I provide qualitative ethnographic examples of how intimate, private and secret uses of smartphones have played out in a Danish social housing area. By focussing on the themes of love and marriage, the imperatives of appearing cool among peers, and keeping the family's honour intact through the display of virtuous behaviour, I show how social media have allowed for multiple versions of the self, for cross-sections of "here" and "there" and for managing public and secret relationships across long distances.

I propose the term composite habitus to analyse the ways in which these young women, like most people in the modern, globalised world, are informed by multiple fields and by multiple forces during their life trajectory. The idea of a composite habitus builds on French sociologist Pierre Bourdieu's take on the concept of habitus ${ }^{3}$-specifically, the writings late in his career on the split habitus. Before discussing this main analytical concept, I shall briefly introduce the applied methodology.

\section{Methodology and the case study}

The material is based on fourteen months fieldwork with young Muslim women between 20 and 30 years-of-age living in a social housing area in Copenhagen. Most of my informants were born in Denmark, although some arrived in their early childhood, and are from Jordanian, Moroccan, Palestinian, Syrian, Iranian, Pakistani, Danish, and mixed origin. Denmark is a small country of 5.6 million people where first and second generation immigrants currently constitute around $11 \%$ of the national population and approximately $22 \%$ of Copenhagen's population (Danmarks Statistik, 2014:11). The area where I worked was one of the areas targeted by the Centre-Right government when launching their "Ghetto strategy" in 2010, whereby 29 areas were designated as ghettos according to three criteria: the percentage of residents unemployed or not in education, the percentage who were immigrants from non-Western countries, and percentage of inhabitants with a criminal record (Ghetto Strategi, 2010:5).

I conducted 8 months of fieldwork "in situ" between February and September 2014, which included both participant observation and collaborative video-making, alongside 6 months of online fieldwork conducted via smartphones and the social media platforms that the women use on these, including most importantly Snapchat, WhatsApp, Facebook, text messaging and telephone conversations (see note 1). Interaction with- and through social media technologies has been central to my research and methodology (Markham, 2004; 2013), yet the use of social media cannot be understood without taking into consideration the ways in which it is intertwined with other contexts and practices beyond the so-called virtual (Ardevol, 2012). The latter 6 months of my online fieldwork was interspersed with 1-2 field visits a month in Copenhagen, during which I stayed at the homes of informants. 
In their lives, on- and offline fields were integrated in complex patterns of socialisation and interaction, and I have strived to adapt my research design to these dynamics 4 . Seen as an extension of self and body (McLuhan, 1964), smartphones help maintain and nurture relationships both near and far, and acts as extensions of real-world practices in concrete places (Miller and Slater, 2000). At the same time, smartphones represent an ever-present portal to other possible lives and futures for my informants; a "technology of the imagination", as it were, (Waltorp, 2013b; Sneath, Holbraad \& Pedersen, 2009), where (self)representation, aesthetics and aspirational politics entwine and merge.

On the one hand, the examples of love on Facebook on which I focus in this article open up an understanding of how young women use smartphones and social media to reproduce moral norms, since they do not publicly question or challenge what should be considered private and what can be public, what is acceptable and not. Yet, on the other hand, their actions signify how the range of possible strategies (Zigon, 2009:254) $)^{5}$ has opened up through their use of social media through which they can conceive of possible ways to challenge moral norms, which thereby become open to them. This paradox of following yet challenging moral norms may also be understood with reference to the composite habitus.

\section{A composite habitus}

Bourdieu famously described in The Logic of Practice (1990) how the habitus is a system of durable dispositions that function as "structured structures predisposed to function as structuring structures" (ibid:53). "Social agents are endowed with habitus, inscribed in their bodies by past experiences", he wrote (Bourdieu 2000:138), underscoring the habitus as a system of bodily embedded experience that makes the individual more disposed to react in one way rather than another (Bourdieu, 1990:66-96). And, as this embodiment of the social, the habitus feels at home in the field from which it is born- the field structures habitus as an internalised product of the immanent necessity of the field. Bourdieu's analytical concept of "field" allows an understanding of the social cosmos as composed of a range of relatively autonomous fields. These microcosms, or force fields, are to be understood as social spaces with specific logics or demands that differ from the conditions and sets of rules of other fields (Bourdieu, 2000:99; Bourdieu \& Waquant, 2009:28, 84-85).

Bourdieu comments in Pascalian Meditations (2000) that he believes it is this mutual adaptation of structure and habitus in his theory that has made critics misunderstand habitus as a principle of repetition and conservation when, in fact, he started working with the concept to understand the mismatches he experienced in Algeria in the 1960s between objective structures and incorporated structures (ibid.:159). In situations of rapid social change or geographical mobility, the mismatch is felt intensely. Bourdieu proposes: There is an inertia in the habitus, or a hysteresis effect, in which "dispositions are out of line with the field...habitus has its 'blips', critical moments when it misfires or is out of phase" (ibid:160, 162). 
In his later work, he opened up to the idea of habitus being split or "clivé", which he also terms a double bind. This double bind/split habitus term is applied in his analysis in The Weight of the World (1999) to denote groups of people in which there is a great variation and, at times, contradiction between experiences and expectations in their families, on the one hand, and those of the educational system and broader society, on the other hand (ibid.:383, 507). When the "structuring of habitus" happens across partially overlapping fields, the tension between them can result in a split, or fragmented, habitus (Bourdieu, 2009:112-13). This resonates with the specific situation of young Muslim women, descendants of immigrants, in my study. It is, in particular, Bourdieu's take on a less unitary habitus in which several dispositions are embodied and act simultaneously as durable dispositions that inspires my analysis. The term composite habitus puts stress on these aspects of the habitus.

Bourdieu scholar Deborah Reed-Danahay has advanced a critique of the habitus concept as too unitary (Reed-Danahay, 2004:156), and her concept of "bi-cultural individuals" (Reed-Danahay, 2000) building on his analytical framework, is an important step in efforts to open up the idea of a closed, unitary habitus, which Bourdieu's own term "split habitus" also points in the direction of (Bourdieu, 1999). I take this one step further, in arguing that the young, "second-generation" immigrant Muslim women inhabit a complex, composite habitus in which they have a range of possible strategies. This does not imply that the composite parts of the habitus can easily be disregarded or applied in a conscious and flexible manner. In working with the composite habitus, I have been inspired by Marilyn Strathern (1988) and Roy Wagner (1981), who have illustrated how Melanesians typically interact as composite beings, constituted of the detached parts, or relationships, of other persons through agentive elicitations and exchanges. It is more multiple predispositions than dual opposing identities that inform the preferences, opinions and choices of my informants.

\section{Composite habitus:}

\section{Two fingers Iranian, three fingers Danish and five fingers Arab}

Bita, 24, the young woman of Iranian origin we met in the opening vignette, is beautiful, veiled, and guards her virginity. She wears clothes that are tight-fitting (but never too tight) and accentuate her slender yet curvy body. She wears makeup that enhances her big brown eyes with extremely long lashes, has a small nose (courtesy of a cosmetic operation in Teheran), and full lips that crack into a broad smile every other minute. Her appearance and charming, fun manner give her status and popularity among peers, but she has to be careful not to become the centre of negative attention and gossip. As her family is "more free", as she says, regarding gender relations, wearing the veil, etc., she is in a slightly different position from that in which my Arab informants seem to be and does not risk provoking her family's anger, disappointment or punishment to the same degree as the others might. 
The uses of social media simultaneously mirror, augment and aid the complex condition of a habitus shaped by composite parts in which young women are informed by multiple forces and take up positions within multiple fields. The quote from Bita below alludes to the idea of a composite habitus in the Wagnerian sense, as being established in the elicitations and exchanges with significant others in the metaphor she offers of "being ten fingers":

\begin{abstract}
Most of my friends are Arab; I grew up with them; I like Arab music and Arab food. I've learned that Arabs always invite you and, if they have something, they offer you. They're generous....Say, if I'm a person, and I'm 100 percent, or, say, I'm 10 fingers: I'm two fingers Iranian, three fingers Danish and, maybe, five fingers Arab, because I grew up here in the area. My mom regrets every day that we moved to this area and that we grew up here. If we had lived somewhere else, we would have spoken a better Danish, and we would've been better integrated and all that. We wouldn't speak this "street language". And if it wasn't because we live here, I wouldn't even bother to wear the veil.
\end{abstract}

Bita is influenced by growing up in Denmark in an Iranian household, visiting family in Teheran, watching Iranian TV and having many Iranian "friends" in various social media platforms. At the same time, most of her friends, whom she has known since early childhood, are Arab and Danish, and they also influence her and make up part of her everyday life. Bita donned the jilbab and hijab (full-length outer garment, and the head scarf showing no hair) years ago but has been undecided as to whether she actually wants to wear the scarf or not. She chose to wear a loose scarf "Iranian/Pakistani style" and does not hide the hair around the forehead and ears. This has been debated among her girlfriends, who accept her for who she is but point to the general sentiment in the local Muslim immigrant community - that you should choose either to wear the veil properly or not at all: "Playing with the scarf is playing with our religion", as two of her friends confided. Bita had been sharing pictures with girlfriends in Snaps and WhatsApp messages without the veil. This is common practice, but her pictures were taken in a café in the city, not within the privacy of a home, which was what spurred debate.

My informants have been influenced by significant others at home and in the local Muslim community, by the (pre)school system in Denmark, as well as a myriad of state and municipal institutions, national media, and everyday life in a Danish city (Gilliam, 2009, Olwig, 2011). These young women are more than "in-between" two different cultures that of their country of origin, on the one hand, and Danish culture, on the other hand. They inhabit and exhibit a habitus, which is formed in the conjunction of the country of origin, the receiving country, the subculture of the social housing project, and the specific mix of other migrants, descendants and Danes in the area. At a popular restaurant owned by Muslim immigrants, a man ripped off Bita's veil from behind, saying in a stern voice, "what is this, on or off with it!" I was shocked when I saw this, but Bita played it cool, covering her hair, and laughingly responded, "So, which do you prefer, if it was up to you?" She 
is skilled in balancing and navigating people's expectations and demands on her and her appearance, and finds ways of asserting herself.

A composite habitus assembles multiple perspectives and develops them in a dialectic movement within a field or, rather, overlapping fields. A composite habitus is not necessarily flexible in the sense of being able effortlessly to bend, adapt and choose from a range of available options. The habitus concept offers this: a reminder of how people do not simply choose consciously to disregard what they have embodied as right, wrong and takenfor-granted - the dispositions are durable. Having a composite habitus with sometimes complementary, sometimes contradictory predispositions can be both an advantage and a challenge. The latter - the challenge and suffering - is what Bourdieu stressed as symptomatic of the split habitus, whereas I hope to draw attention to both the limiting and productive potentials. This composite condition might be argued to be an overall condition of modern societies. Yet, this is especially accentuated for the young Muslim (secondgeneration) immigrant women living in social housing areas in European cities.

\section{Social media platforms and their (in)visible uses}

Many of my informants have profiles on semi-public social media sites such as Facebook. On these sites, they share their devotion to the Prophet Muhammad and his teachings. These displays have their own recognizable aesthetic with pictures and drawings, often quoting ayat (verses in the Qur'an), shared on the person's Facebook wall. However, these posts also communicate different opinions and sentiments to discrete others. Depending on how intimately the audience knows the person posting these images and quotations, different readings are possible. In some instances, family members are keeping a close watch on subtle messages being sent and posted on Facebook - responding to a practice that is already well in place.

On the "official" Facebook pages, where people use their real names and pictures, content range from food, fashion and beauty, children and family gatherings, certain political crises and causes (Palestine, Syria), work/study related posting, etc. shared on the Facebook wall. All this belongs to a public online sphere. Simultaneously, young women carve out spaces for themselves in which they modify, censor and reveal, depending on audience and context - within otherwise seemingly very "public" platforms.

Older forms of media, especially TV, also make up part of this mix as more private discussions in the home become more public and shared through social media: Scenes that people particularly liked or disliked in popular TV series, such as Noor and other soap operas, are shared on Facebook or linked to on YouTube and, thereby, spur debate on moral issues (Waltorp, 2013b, Salamandra 2012). Sometimes this is done as a Snapchat message, taking a snap-photo of the TV screen while watching a broadcast of a TV series, writing comments directly on the picture before it is sent. My informants have explained how the popularity of the TV series makes it possible to discuss moral issues on safe ground 
across generations through the interactions of the protagonists in the soap opera - issues such as sex before marriage, drinking in public places, (im)proper dress, and gender roles that might otherwise be seen as very personal and controversial to bring up.

As I became more familiar with my informants and spent more face-to-face time with them in their homes, I learned about the different ways of communicating on social media platforms, "Snapping pictures" and using various other popular Apps such as WhatsApp (which integrates text, photos and, sometimes, film clips), and Facebook. Most of my informants only use Instagram's visual platform and the personal comments and statements in Twitter to communicate with a select group of people. They discern closely who is allowed to see what, who to trust with what, and when: Secrecy, (in)visibility and timing are of the essence. This might be seen as a common dynamic related to impression management and role conflict (Goffman, 1959; 1970).

Texting and calling are done frequently and at all hours by most of my informants. They seldom spend a day without being in contact with their close family and friends. This also means that Tango and Viber (having taken over the platform that Skype previously occupied as the primary face-to-face video phone service) are often used to communicate with siblings who have married and settled either in their parents' countries of origin or neighbouring countries.

In semi-public and intimate spaces both on- and offline, these young women act out and experiment with accepted, virtuous versions of themselves and try out behaviour and relations that would otherwise be gossiped about if they occurred in public. Gossip-invoking behaviour in these cases would have been detrimental to the woman's reputation and, consequently, to that of her family as well.

\section{Belonging: Children of immigrants}

Rania, 25, of Syrian origin, highlights an idea of shared experience and shared understanding between young Muslim people born and raised in Denmark. This is what sets them apart from other young people who are born and raised in their parents' countries of origin:

\footnotetext{
I know a lot of Danish people, but none of my closest friends are Danish. Also, none of my best friends are Syrian girls who live in Syria. I don't think they would become my closest friends, even if I went and lived there now. My best friends are Syrian or other Arab, Muslim girls - but who grew up here, like me. I would also like my future husband to be Muslim, but from Europe, and brought up here: So, there's a better understanding.
}

As Rania points out in the quote above, none of her closest friends are Danish, nor are they girls who live in Syria. Those friends with whom she is most at ease and naturally connects are other Muslim Arab girls who grew up in Denmark - in other words, with backgrounds similar to hers. This points to a composite habitus that is not shaped by parents or their country of origin nor by Denmark, as such, but is a part of an identity shared by being in 
the same boat as other descendants of Muslim immigrants to Europe and being able to relate to each other's experiences. It also points to an intergenerational divide in immigrant families, as this is a position they do not share with their parents. This specific instance of Bourdieu's split habitus, has been studied by his close associate, sociologist Abdelmalek Sayad (1979, 2004).

In Les Enfants Illegitimes (1979), Sayad elaborates on an extended interview with the young woman Zahouda, who was born in France to Algerian parents. In the interview, she keeps returning to her experience of feeling almost like an illegitimate child, as her own parents do not recognize themselves in her. She, along with those of her siblings who were also born in France, had become too French according to their parents. Zahouda describes her experiences of visiting Algeria and how she was unable to fit in, understand the codes, the tacit knowledge of how to move, talk, and behave. Yet, in France, as she says, she would be seen as Algerian. This experience mirrors that of several of my informants:

\footnotetext{
You can be born in Denmark, grow up here, but you're not Danish (in the eyes of ethnic Danes) - and the minute you set foot in Jordan, they know that you're not from there: Then, you're suddenly Danish. They see it right away: the way we dress, the way we move, simply the way we look at them! We have a different way of looking, I've been told. (Hadia, 22, Dane of Jordanian origin).
}

What, then, could be considered as being "at home", where there is an unquestioned fit between habitus and field? I propose that feelings of belonging and feeling connected are mediated by social media in new ways for this group of young Muslim women in Denmark.

A difference from Sayad's study of Algerian immigrants in France in the 1960s, '70s, and ' 80 s and of particular interest to the argument I put forward here is that, at the time he was conducting his research, smartphones and social media were not available. Hence, the way in which these technologies afford opportunities to negotiate one's place in the world was not present among his informants, as it is today.

\section{Being connected}

A number of my informants have married and settled in their parents' country of origin or other Arab countries, and most of them have sisters or girlfriends who have done so. Dubai is a popular place, according to my informants, because "[i]t is like a European city, but at the same time it is a Muslim and Arab city". Copenhagen remains the preferred place to live, however. Through social media such as WhatsApp groups, which connect siblings across European and Arab countries, my informants have kept in daily contact with sisters and other family members, updating each other with texts, photos, shared content, and so forth.

Rania, whom I introduced above, told me of her experiences of moving back to Syria with her family while she was still in middle school. Along with her sisters, she had longed 
for Syria and loved their holidays there; yet, when they lived there, they longed for everyday life in Denmark. They longed for rye bread and similar little, taken-for-granted things in Denmark that makes one feel at home. After eight months, her parents decided to move back to Denmark for good, since none of their children were able to adjust to life in Syria. However, Rania has kept in regular contact with her family and friends in Syria and Jordan through social media.

According to Bourdieu, migration entails a rupture in that the conditions for the production of habitus are not "homologous to its conditions of functioning" and "practices are always liable to incur negative sanctions when the environment with which they are actually confronted is too distant from that to which they are objectively fitted." (Bourdieu 1977:78). He sees that intergenerational conflicts solicit not age classes separated by natural properties but forms of habitus that have been produced by different modes of generations: "by conditions of existence which, in imposing different definitions of the impossible, the possible, and the probable, cause one group to experience as natural or reasonable, practices or aspirations which another group finds unthinkable or scandalous" (ibid.). These conflicts between the impossible and possible are indicative of the intergenerational relations among the Muslim families of my informants.

To sum up, what the young Muslim women in social housing share is the feeling of being estranged from their parents' country of origin as well as their embodied habitus and worldviews from these countries of origin, similar to the experience of the informants of Bourdieu (1999) and Sayad $(1979,2004)$ in the French context. At the same time, they share many values, ideas and habits with their parents. The young women tacitly embody and share values with their parents and pose questions and hold other values and beliefs that are apparently contradictory. Below is an example of how conflict in the family can be sparked by the fear that the younger generation will be influenced by amoral behaviour and the wish to protect them as well as the honour of the extended family.

\section{Navigating social media}

A seemingly innocent status update on Facebook by a young woman, Hadia, 22, of Jordanian origin, read: "Oh, I feel so happy today $(-)$....". The update stirred controversy among several of her uncles, however. The uncles contacted her mother and asked her to control her daughter and be aware of "what people might think". They implied that people could start talking about Hadia being happy for "non-virtuous" reasons, since the update could be read as implying a relationship to a man who was making her happy. The mother was in tears, and the incident made an impact on the whole family. Discussions ensued regarding what takes place in social media.

Hadia, then, did what many young women do: She deactivated her account, only to re-emerge under a new profile with a different name and with no pictures of herself that might lead a larger audience to identify her. She became very restrictive regarding whom 
she allowed to be her "friend" under her alias profile. The strategy of changing her social media identity involves hyper-vigilance, and new types of behaviour, where especially young women activate and de-activate profiles. As we see here in Hadia's story, the smartphone and the virtual arenas it opened up became highly contested; and what some senior family members perceived as looking out for the young woman's honour and, thus, the honour of the whole family, was more of a grey zone for many of the young women I spent time with.

The concept of honour as I use it here is intimately related to Islam, to piety and propriety, to gender relations and the guarding of women's virginity, and to sexuality (Eickelman, 1976; Salvatore \& Eickelman, 2006) ${ }^{6}$, and it also contains local traits and inspiration from the Danish context in which it works. The constant concern about harmful gossip often works as a strong control mechanism. It is important to point out in the context of this discussion that ideas of public/private spaces among informants and related ideas of proper behaviour in different spaces, seem to offer frameworks for rich same-sex sociability with frequent visits, informal home parties, and large parties (engagements, weddings) at banquet halls with 200-300 women dressed in festive attire, unveiled, dancing to DJs playing both popular Arabic tunes and Western hit songs. In these same-sex spaces, the young women can display other versions of themselves than what they display in Danish public spaces with both men and women present.

In social media, they carve out additional spaces in which they play with identities or sides of themselves that seem to be informed by overlapping ideas of public/private in new ways. A key issue concerns the ways in which these young Muslim women seek to "augment their social being" as Bourdieu puts it (Bourdieu, 1993:274 in Hage, 2014:142) by extending their typical appearance in public (veiled and dressed in a modest way) to virtual spaces in which they live out and produce the composite habitus. They do this by playing with alternative ways of representing, expressing and being themselves; sending pictures to close friends (or even a secret boyfriend) without the veil, wearing beautiful make-up, pouting and posing in sexy positions. This mode of communicating in social media is always done discreetly. Discreetly in this context means that this sort of content would never find its way onto the public Facebook wall but is kept within private messages in WhatsApp or Snaps.

Engagement with social media has become a contested practice and has the potential to make these young women appear immoral if secret, discrete behaviour is revealed. A disclosure of such clandestine activities would be shameful and the consequences unbearable, including a loss of social status for both the woman and her family and, potentially, also exclusion from the family and community.

The fear of social exclusion and of being categorised as a "whore" (luder) in the eyes of others represents the most frightful sanction. This has consequences for marriage opportunities, not just for oneself but, potentially, for one's siblings, too. This is one reason sisters keep an eye on each other, making sure that no one acts indiscreetly or in ways that are detrimental to the family's honour. As Hadia says, underscoring the fear of what would happen 
should she dishonour the family and be rejected by them: "Without my family, if they would throw you out...then, you're nothing, just someone in the gutter". As mentioned, the young women express agreement with and adhere to many of the values that the older generation holds high. Simultaneously and apparently paradoxically, they partake in social media communication in a skilled, secretive way, applied with respectful discretion.

With the high risks involved, fearing sanctions by their family - for example, turning their back on them, why do the young women engage in social media (including relations with young men) at all? How can we understand this precarious practice? I see my informants' actions as a struggle to augment their social being, which seems to pull them in different directions. Bourdieu defended himself against misinterpretations of his theory as a purely economic framework, with agents driven by interests and the need to accumulate capital and maximize profit, saying: "It is not true to say that everything that people do or say is aimed at maximizing their profit; but one may say that they do it to perpetuate or to augment their social being" (Bourdieu, 1993:274 in Hage, 2014:142). Understanding this struggle to augment one's social being through the analytical concept of the composite habitus allows us to understand the social agent as skilfully navigating social media spaces and drawing upon different moral and aesthetic codes.

\section{(Arranged) marriages and Facebook debate}

Several informants visit or follow Facebook pages and groups, where experiences and issues around what it means to be a (young) Muslim in Denmark are shared and debated. An example of such a Facebook page is the page "Det Bar' Ayib" (ayib meaning embarrassing or inappropriate/rude/awkward). The administrators of the page allow anonymous blog posts on the Facebook wall once in a while, putting on the agenda issues such as arranged marriage vs. forced marriage, homosexuality, being "cheap" vs. being generous, and other topics. The discussion on arranged marriages and the good/bad aspects of it had over 400 comments on the thread within a few days. The very different opinions voiced on these media platforms also show to the young women themselves how broad the definition of the good Muslim can be within the Muslim community in Denmark (see also Piela, 2010). The social media platforms, thus, accommodate explicit debates, and facilitate concrete actions when pursuing love. A video has circulated on Facebook in the network of some of my informants, warning against the misfortunes befalling a girl who is lured into contact with a young man through Facebook. In this video, the exchange starts very innocently but ends up with actual meetings in a park, where pictures are taken that are later used by the young man to pressure the girl to meet him again, even as she is about to marry another man. She is caught in this dilemma and ends up taking her own life in order not to cast shame on her family. The video ends by advising strongly that parents and brothers look out for their sisters' wellbeing by being alert to what can take place in social media, so that they do not end up in such an unfortunate situation. 
Some of my informants have, or have had, relations with young men. Some of these relationships take place solely online; others developed outside 'the grid' of arranged marriage; and yet others transform into morally sanctioned marriages, that is, if the young woman plays her hand well. Playing your hand well involves letting parents take over at the appropriate time. Those of my informants who are married had in some instances been living in arranged marriages that were more or less freely chosen liaisons. One informant did not have any say in her marriage: She was taken out of $8^{\text {th }}$ grade by her parents and married off at the age of 16 to a cousin 12 years her senior. Another informant met her future husband at the university while she was studying. After slowly getting to know each other (albeit not physically), falling in love and, they introduced the idea of future marriage to their parents, who then took over from there. These two informants represent two opposing poles in terms of how much/little they were individually involved as driving forces in their own marriage - and the other informants fall in between these two poles.

Several of my unmarried informants received marriage proposals or requests to begin conversations toward that end via their parents, who were contacted by the parents of a suitor. The dynamic in each family was different: Some of the young women simply turned down the prospect of marriage, which was accepted by their parents; others had some say in the matter but might have experienced more pressure in the process. Some of the conflicts and divergent wishes regarding marriage and romantic love can be traced to the fact that the concepts of love and marriage seem to be quite different between the younger and older generation: Is marriage about securing the larger family, building a strong foundation and secure a viable liaison for your offspring? Or is it about finding the one and only, that significant other to whom you are attracted and with whom you fall in love - someone who makes you feel special and with whom you want to start a family and spend the rest of your life? The older generation express - and is perceived as having - clearer ideas regarding marriage than the younger generation (even though they might have experienced similar dilemmas).

Rania was approached at one point in her life, when she was not keen on the prospect of marriage:

There are just so many things that I want to do, I want to experience and achieve, before I want to get married. I want to finish my education! No, no, no - I don't want to get married at this point in my life. Surely, nothing will come of this. It's just one of those things - at least, for an Arab girl. Surely nothing will come of this.

A couple of years later, after having finished her education and while looking for a job to no avail, she received another offer through her family. This time, she felt differently about the prospect of marriage. In the end, her father and the suitor did not agree on a suitable bride price, and the arrangement was broken off. Rania was sorry the process broke down, especially after she and her suitor had gotten to know each other quite well through Skype. Later, a similar process worked out, and she is now married and living in Dubai. This is an 
example of how an arranged marriage can pass through various phases, courtesy of social media, in which the young people have an opportunity to get to know each other over time and to see how they feel about the proposed arrangement.

\section{Aansa and the romantic potentiality in Facebook}

Aansa, 30, of Pakistani origin, was introduced, virtually through her network, to a Pakistani suitor from Britain. He was shown her Facebook profile "to get a feel of what kind of person she was". They went through the steps of checking out each other's public profiles in social media, then communicating via SMS, calling each other and, finally, arranging for the potential suitor to come to Denmark.

Ansaa met her previous boyfriend through Facebook, too, and they secretly kept in contact through Facebook, WhatsApp, text messages and calls. In this way, Facebook has the potential of containing many hidden and private places where you can get in contact and communicate without it ever becoming public or traceable. Her secret lover was told that he was to marry a cousin, whom he never met. He was stressed about the situation, started losing hair, but he could not bring it upon himself to disappoint his family, who value social standing and caste highly. His brother had disappointed the family by "choosing love" and marrying someone other than the woman they would have preferred. Now, the younger brother was not it any position to choose Aansa over his cousin. The honour of the whole family would suffer, and he had to uphold it by "doing the right thing". Their relationship ended when he married. In this instance, it was the young man who was pressured by his family, whereas the young woman's family would have accepted the liaison. One of Aansa's sisters married a Danish (converted) Muslim man; another married and moved back to Pakistan. They all kept in contact through social media. She herself was open to whatever life and marriage might bring her: "If it is a good Muslim man, so we agree on how to bring up our children, and if the financial situation is in order, I would go to Pakistan". She preferred to stay in Copenhagen but was also ready to move to England, if the relationship with the young man with whom she was communicating in social media had evolved in a different direction.

The complex situation of trying to accommodate individual wishes and desires with expectations from the family may not be anything new, but the arenas and the ways in which this played out among these young women have changed with the introduction of smartphones and new media technologies.

\section{Messages with multiple layers}

\section{- from poetry to social media and surveillance}

In her monograph Veiled Sentiments (1986), anthropologist Lila Abu-Lughod writes extensively on the subject of honour as intricately related to the wearing of the veil and relations 
between the sexes in Islam. I see parallels in the way the Bedouin women she worked with use poetry (ghinnawa) as a vehicle to express (non-virtuous) sentiments that are not necessarily talked about in the open and how my informants communicate (secret) messages layered with multiple meanings and sentiments in social media.

My informants know how to conduct themselves in both private and public spaces on- and offline. They have a "feel for the game" with a practical sense of how to "perform" (Bourdieu, 1990:66-67), how to avoid negative attention by living up to the kind of modest behaviour expected of a young Muslim woman, and how to dress, greet people politely in the public sphere, etc. They know when and where they can "let loose" in the company of peers (of the same sex), yet out of sight of the older generation or others who do not have their trust, who might be likely to gossip and "be headache" (være hovedpine): People "being headache" might include talking about them wearing too much make-up, being out too late, or being in the company of men who are not family or known by their family, etc. In short, they know how to be respectful and discreet in terms of where, when and what kind of behaviour is appropriate and expected, just as they know what content and tone has to be kept within private messages or in an inbox that can be shared in a closed Facebook or WhatsApp group and what can be shared on a Facebook wall.

The smartphone and social media in general do not hold unbridled transformative potential, as the surveillance the social media allows for is highly problematic. As we saw in the case of Hadia's Facebook post on being happy, this skilful "knowing" is somehow not secure; it is always a negotiation. One cannot know what consequences a public post on social media may incur. The young Muslim women I worked with agree that, in the area in which they live, everyone will gossip and have an opinion about their appearance.

Hélène, a social worker of many years in the area, reports that many brothers and fathers have a system whereby their sister/daughter must send a text message indicating her whereabouts every 30 minutes if outside the home. If she fails to do so, she will be punished (potentially, physically). Hélène has experienced examples of abuse by parents and brothers towards their daughter/sister and explains how text messaging and telephoning is not necessarily a "private" space for the young women, as parents will take the mobile telephone and monitor their calls and the content of text messages sent. She herself has been called numerous times by concerned parents when her number has shown up in the list of outgoing calls on young women's smartphones. The concerned parents wished to know with whom their daughter was in contact and what the nature of their relationship might be. Neighbours watch each other, Hélène stresses, and strict rules apply for young women (Waltorp, 2013a).

It is important to keep in mind that concepts such as "social control", often used in conjunction with "ethnic minorities", denote everything from socialisation to the extreme of (physical) sanctions on individuals' unwanted behaviour by the group. Most of my informants have experienced calls and questions if they had been out longer than what was agreed on or without informing their husband/parents of their whereabouts. The expres- 
sion of someone "being headache" mirrors the pressure and irritation in the face of the pervasive control mechanism that regulates behaviour by the very fear of the potential consequences of other people's surveillance and subsequent gossip. It is a habituated state whereby the young women automatically remain alert, monitoring who is able to see them and to listen in on a conversation. Gossip is an ever-present danger, and the family's loss of honour the dreaded consequence. Pictures or short video clips from places that are not strictly indicative of a good or virtuous woman are only sent via Apps to intimate friends who are trusted to keep them secret.

Most of the young women censored themselves by not uploading pictures taken in a public place after a certain time and by paying attention to what is expected of them, as do all young people to some extent, when discerning what version of themselves they want to project to their friends vs. those they want to present to their parents (boyd \& Marwick, 2011). In the company of (Danish) friends who meet other restrictions than the ones with which they have personally been brought up, my informants might downplay sides of themselves. Social media is a way to "augment their social being" by keeping cool among friends (and, perhaps, a boyfriend) without crossing any lines that make it impossible to remain, and be seen as, virtuous at the same time. The composite habitus helps understand how they navigate other people's differing expectations of them and their own, sometimes contradictory, expectations of themselves.

\section{Conclusion}

Building on ethnographic fieldwork with young Muslim women in a Danish social housing area, this article has sought to explore the role that the uses of social media have played in young women's positioning in multiple spheres, or fields, when seen through the analytical prism of Bourdieu's habitus concept.

I have presented empirical examples of how young Muslim women draw upon and use social media to enable both legitimate contact and "clandestine" relationships in order, thus, to "augment their social being" in different ways and to pursue otherwise seemingly incompatible strategies, namely, aspirations for love and maintaining the family's honour through the public display of virtuous behaviour. Discreetly, these young women negotiate morality between themselves and their girlfriends, experiment and push boundaries, and extend the "range of possibilities" through the use of social media: keeping cool and staying virtuous.

Engaging in the field of social media might allow for negotiating paradoxes and navigating between conflicting desires and expectations in everyday life, if not resolving or dissolving these conflicts and paradoxes. This is not to imply that another set of challenges and risks is not introduced as part of these new practices. There are multiple parallel, overlapping fields that are managed through these uses of the social media, turning the smartphone into a portal to other possible lives, ways of relating, and experimental acts. At the 
same time, there is the ever-present control and monitoring of self and others. In this way, the uses of social media mirror, augment, and aid the conditions for - and are productive of - a composite habitus.

Are the smartphone and social media merely a valve for young Muslim women's various desires for expressing themselves and forging relations, while not actually changing the status quo, enacting "part-revolutions", as Bourdieu calls it (2001:119)? Or do ideals about morality and modesty and gender and generational relations become reconfigured in the ways in which young women use the smartphone and social media to navigate their everyday contested and monitored lives? This warrants further studies.

\section{References}

Abu-Lughod, L. (1986). Veiled Sentiments - Honor and Poetry in a Bedouin Society. Berkeley: University of California Press.

Appadurai, A. (1986). 'Theory in Anthropology: Center and Periphery'. Comparative Studies in Society and History, 28 (2): 356-361.

Ardévol, E. (2012). 'Virtual/Visual Ethnography: Methodological Crossroads at the Intersection of Visual and Internet Research'. In Pink, S. (Ed.), Advances in Visual Methodology Anderson. SC: Parlor Press: 74-93.

Bourdieu, P. (1977). Outline of a Theory of Practice. Cambridge: Cambridge University Press.

Bourdieu, P. (1984). Distinction: A Social Critique of the Judgement of Taste. New York and London: Routledge Press.

Bourdieu, P. (1990). The Logic of Practice. Cambridge: Blackwell Publishers.

Bourdieu, P. et al. (1999). The Weight of the World. Social Suffering in Contemporary Society. California: Stanford University Press.

Bourdieu, P. (2000). Pascalian Meditations. Cambridge: Polity Press.

Bourdieu, P. (2001). Men hvem skabte skaberne. København: Akademisk Forlag.

Bourdieu, P. \& L. Waquant. (2009). Refleksiv Sociologi - Mål og midler. København: Hans Reitzels Forlag.

boyd, danah and Alice E. Marwick (2011). 'Social Privacy in Networked Publics: Teens' Attitudes, Practices, and Strategies'. Presented at A Decade in Internet Time: Symposium on the Dynamics of the Internet and Society. Available at SSRN: http://ssrn.com/abstract=1925128

Couldry, N. (2013). 'Life Without Media: Or, Why Mediacentrism Is Bad for You'. In: Comas, E., Cuenca, J. and Zilles, K., (Eds.) Life Without Media. New York: Peter Lang Publishing: 27-41.

Couldry, N. (2005). 'The Individual Point of View: Learning from Bourdieu's 'The Weight of the World". Cultural Studies - Critical Methodologies, 5 (3): 354-372.

Danmarks Statistik (2014). Indvandrere i Danmark. (http://www.dst.dk/pukora/epub/upload/19004/indv. pdf)

Eickelman, D.F. (1976). Moroccan Islam: Tradition and Society in a Pilgrimage Center. Austin: University of Texas Press.

Goffman, E. (1959). The Presentation of Self in Everyday Life. New York: Doubleday Anchor Books.

Goffman, E. (1970). Relations in Public: Microstudies of the public order. New York: Harper \& Row.

Ghetto Strategi (2010). Ghettoen tilbage til samfundet. Available at: www.stm.dk/publikationer/Ghettostrategi_10/Ghettostrategi.pdf 
Gilliam, L. (2009). De umulige børn og det ordentlige menneske: identitet, ballade og muslimske fallesskaber blandt etniske minoritetsbørn. Århus: Aarhus Universitetsforlag,

Hage, G. (2014). 'Eavesdropping on Bourdieu's Philosophers'. In Das. V., M. Jackson, A. Kleinman, B. Singh (Eds.). The Ground Between: Anthropologists Engage Philosophy. Durham NC: Duke University Press: 138-158.

Hepp, A. (2010) 'Researching 'Mediatized Worlds': Non-media-centric Media and

Communication Research as a Challenge'. In Carpentier, N., I.T. Trivundza, P. Prulmann-Vengerfeldt, E. Sundin, T. Olsson, R. Kilborn, H. Nieminen, Hann, B. Cammaerts (Eds.) Media and Communication Studies. Interventions and Intersections. Tartu: Tartu University Press: 37-48.

Markham, A. (2004). 'Internet Communication as a Tool for Qualitative Research'. In Silverman, D. (Ed.). Qualitative Research: Theory, Method, and Practices ( $2^{\text {nd }}$ Edition). London: Sage.

Markham, A. (2013).' Fieldwork in social media: What would Malinowski do?' Journal of Qualitative Communication Research, 2(4): 434-446.

McLuhan, M. (1964). Understanding Media. The Extensions of Man. Massachusetts: MIT Press.

Miller, D. \& D. Slater (2000). The Internet: an ethnographic approach. Oxford and New York: Berg.

Morley, (2009). 'For a Materialist, Non-Media-centric Media Studies'. Television \& New Media 10 (1): 114-116.

Olwig, K. (2011). “Integration': Migrants and Refugees between Scandinavian Welfare Societies and Family Relations.' Journal of Ethnic and Migration Studies, 37 (2): 179-196.

Piela, A. (2010). 'Muslim Women's Online Discussions of Gender Relations in Islam'. Journal of Muslim Minority Affairs, Vol. 30 (3): 425-35.

Reed-Danahay, D. (2004). Locating Bourdieu. Bloomington \& Indianapolis: Indiana: Indiana University Press.

Reed-Danahay, D. (2000). 'Habitus and Cultural Identity: Home/School Relationships in Rural France'. Pp. 223-236 in Levinson, B. et al. (2000). Schooling the Symbolic Animal. Oxford: Rowman and Littlefield Publishers.

Salamandra, C. (2012). 'The Mohanad Effect. Media Panic, Melodrama, and the Arab Female Gaze'. Anthropological Quarterly, 85 (1): 45-77.

Salvatore, A. \& D.F. Eickelman (2006). 'Muslim Publics. In Salvatore, A \& D.F. Eickelman' (Eds.) Public Islam and the Common Good. Leiden: E.J. Brill: 3-27.

Sayad, A. (2004). Suffering of the Immigrant. Cambridge: Polity Press.

Sayad, A. (1979). 'Les enfants illégitimes' (1ère partie). Actes de la recherche en sciences sociales 25, Le pouvoir des mots: 61-81.

Slater, D. and D. Miller. (2000) The Internet: An Ethnographic Approach. Oxford: Berg Publishers.

Sneath, D., M. Holbraad \& M. Pedersen. (2009). 'Technologies of the Imagination: An Introduction'. Ethnos 74(1): 5-30.

Strathern, M. (1988). The Gender of the Gift: Problems with Women and

Problems with Society in Melanesia. Berkeley and Los Angeles: University of California Press.

Wagner, R. (1981). The Invention of Culture. London \& Chicago: University of Chicago Press.

Waltorp, K. (2013a). 'Public/private negotiations in the media uses of young Muslim women in Copenhagen: Gendered social control and the technology-enabled moral laboratories of a multicultural city'. International Communication Gazette, 'Mediated Urbanism', vol. 75 (5-6): 555-572.

Waltorp, K. (2013b). 'Sæbeopera som forestillingsgenererende teknologi'. Antropologi, 'Verden(er)' vol. 67: 139-155.

Zigon, J. (2009). 'Within a Range of Possibilities: Morality and Ethics in Social Life'. Ethnos 74 (2): 251-276. 


\title{
Notes
}

1 Facebook is the largest social (networking) site, which affords both public displays on "the wall" as well as private communication in an inbox. The inbox can be used for communication without being "friends", so that other contacts on Facebook cannot see that you are linked to the person in question. So-called "Snaps" are sent from the "Snapchat" photo messaging application that allows users to take photos, record videos, add text and drawings, and send them to a controlled list of recipients. The content is deleted after a set time limit of maximum 10 seconds. The "WhatsApp" application integrates photos, text and small videos but, unlike Snapchat, content is not deleted automatically. "FaceTime" is a videotelephony/voice over IP (VoIP), and "Viber" is an instant messaging and Voice over IP (VoIP) app: In addition to instant messaging, users can exchange images, video and audio media messages.

2 See note 1 for an explanation of all applications mentioned in the article.

3 According to Bourdieu, all the thinkers who have worked with the concept habitus - from Hegel's ethos, Husserl's Habitualität to Mauss' hexis - have been engaged in a theoretical project of how to free oneself from a subject philosophy without giving up on agency. (Bourdieu, 2009:107).

4 My contribution to media studies could be seen as an example of what scholars have called 'non-mediacentric media and communication research' (Couldry, 2013; Hepp, 2010; Morley, 2009).

5 Jarett Zigon (2009) discusses the moral range of possibilities that appear in the face of moral breakdown, moments in which people consciously reflect on ethics. He uses the term moral habitus (however, without referencing Bourdieu but Mauss).

6 'Honor-and-shame' has been a "gate-keeping concept" (Appadurai, 1986:357) for the circum-mediterranean area and the Middle East because of its pervasiveness in anthropological studies here.

\author{
Karen Waltorp \\ Ph.D. fellow \\ Department of Anthropology \\ Aarhus University \\ etnkw@cas.au.dk
}

